\title{
Analysis of promising walnut forms for resistance to return frost
}

\author{
Larisa Artyukhova*
}

Federal State Budget Scientific Institution «North Caucasian Federal Scientific Center of Horticulture, Viticulture, Wine-making», str. 40 Let Pobedy, 39, Krasnodar, 350901, Russia

\begin{abstract}
In the conditions of the central zone of the North Caucasian region of Russia, in recent years, a tendency has been noted to increase the negative impact of low-temperature stressors of the winter and spring periods on walnut plants (Juglans regia L). The purpose of the study is to identify the most valuable genotypes for creating walnut varieties with increased resistance to cold stress, promising for cultivation in the south of Russia. Modern programs and methods of breeding and variety study were used. The results of a long-term study (2019-2021) of collection samples of walnuts growing in the conditions of the central zone of the North Caucasus region are presented. Highlighted hybrid forms of walnut with an early start of the growing season: 17-2-41, 17-3-44, 17-2-35, 17-2-26 (from hybrid families Ideal f. p., I -Yu-50 f. p.); and especially valuable for breeding and production genotypes with a late start of the growing season: 17-3-48, 17-3-16, 17-3-22, 17-3-19 (Dachny f. p., Ya-B-84 f. p.). It has been established that all hybrid seedlings from families (Ideal f. p., Ya-Yu-50 f. p., Ya-Yu-40 f. p., Dachny f. p.) of walnut are moderately resistant to returnable spring Frost.
\end{abstract}

\section{Introduction}

In the North Caucasus region, a predominantly unstable and often rather harsh climate prevails for the cultivation of walnuts. Walnut (Juglans regia L.) is distinguished by a short period of winter dormancy, the most important for it are the weather conditions of the winterspring period. [1-2]. Consequently, areas where frosts often occur after the blooming of fruit buds, leading to their freezing, are considered unsuitable for industrial cultivation of fruit crops, including walnuts [3-6]. For this reason, freezing is often an important selection criterion in breeding programs, and in a number of research programs, the main emphasis is placed on breeding varieties that are resistant to low temperatures [5, 7-8]. Low temperatures for walnuts are the main limiting factor that can explain the spread of species in cold climates [9-10]. The relevance of this problem determines the setting of the goal and objectives of breeding for a given culture. The aim of the study is to identify the most valuable genotypes for creating walnut varieties with increased resistance to cold stress, promising for cultivation in the south of Russia. It should be noted that no matter how good the variety is in terms of

\footnotetext{
* Corresponding author: Larisa.Artyuhowa@yandex.ru
} 
fruit quality and other agrobiological traits and properties, it cannot become widespread in the southern region if it is characterized by insufficient winter hardiness [11-15].

\section{Materials and methods}

The research was carried out in 2019-2021 in a breeding garden in the Central part of the Prikubanskaya zone of gardening of the Krasnodar region, on the basis of the (ZAO Experimental Production Farming "Tsentralnoye"), NCFSCHVW in Krasnodar. The objects of research are promising hybrid forms of local walnut selection. The garden was planted in 2014, the layout was $5 \times 4 \mathrm{~m}$. Field and laboratory research methods were used in the work. The research was carried out in NCFSCHVW, in the center of collective use "Research and selection collection of genetic resources of horticultural crops". Research was carried out according to programs and methods: "Program of the North Caucasus Center for the selection of fruit, berry, flower and ornamental crops and grapes for the period up to 2030"; "Modern methodological aspects of the organization of the selection process in horticulture and viticulture"; "Program and methodology for the study of varieties of fruit, berry and nut crops." For the analysis of meteorological conditions, we used the data of the agrometeorological station M-2, Krasnodar.

The climatic conditions of the Prikubanskiy zone of gardening in the Krasnodar region are generally suitable for growing adaptive varieties of walnuts in the private sector and farms. Weather conditions over the years of research in the area of the experimental site were characterized by the following features. Winter in the central zone of the Krasnodar region during the observation period from 2019-2021. was quite mild, with a minimum temperature in January $2021\left(-17.5^{\circ} \mathrm{C}\right)$. The spring months of 2019 were characterized by a rapid increase in positive temperatures with a significant increase by $3.0-4.1{ }^{\circ} \mathrm{C}$ above the norm. The average air temperature in March reached $+6.4^{\circ} \mathrm{C}$, and in April $11.9^{\circ} \mathrm{C}$. Also, in March, throughout the decade, a decrease in air temperature from $-0.1{ }^{\circ} \mathrm{C}$ to $-2.9{ }^{\circ} \mathrm{C}$ was noted, as well as in the first decade of April to $-1.2^{\circ} \mathrm{C}$. Unlike the previous year, the spring of 2020 was distinguished by the presence of stresses, with a significant increase in air temperature above normal in March by $9.1^{\circ} \mathrm{C}$ and a sharp decrease in the first and second ten days of April by $2.3{ }^{\circ} \mathrm{C}$ below normal. The growing season took place in unfavorable conditions, in the second decade of March, a decrease in air temperature to $-5.0^{\circ} \mathrm{C}$ was noted, in April, in the first and in the second decade at night, there were frosts from $-1.2{ }^{\circ} \mathrm{C}$ to $-2.7{ }^{\circ} \mathrm{C}$. The average air temperature in March reached $+9.3{ }^{\circ} \mathrm{C}$, and in April $+10.4{ }^{\circ} \mathrm{C}$. The spring of 2021 was quite rainy and cool, the average air temperature in March was $2.0^{\circ} \mathrm{C}$ below normal with a decrease in air temperature in the second decade to $-7.9^{\circ} \mathrm{C}$. Precipitation fell throughout the decade in the form of snow and rain. In April, the average air temperature was also $0.2^{\circ} \mathrm{C}$ below normal, with a minimum temperature drop in the first half of the decade to $+1.5^{\circ} \mathrm{C}$. The average temperature in March was $+4.5^{\circ} \mathrm{C}$, and in April $+1.1^{\circ} \mathrm{C}$. The vegetation period of the walnut depends entirely on the interannual - temperature changes.

\section{Results and discussion}

In the spring, the plant is most sensitive to temperature extremes, which is reflected in the growing season (table 1).

The beginning of the growing season in 2019 varied from 6 to 12 April, the sum of active temperatures at the start of the growing season was from 224 to $309^{\circ} \mathrm{C}$. The difference at the beginning of the growing season between the early and late hybrid forms was 6 days. 
Table 1. Dates of the beginning of the growing season and the sum of active temperatures by years of hybrid forms of walnut, for 2019-2021.

\begin{tabular}{|c|c|c|c|c|c|c|}
\hline \multirow{2}{*}{$\begin{array}{l}\text { Variety, } \\
\text { the form }\end{array}$} & \multicolumn{3}{|c|}{$\begin{array}{l}\text { The beginning of the growing } \\
\text { season by years }\end{array}$} & \multicolumn{2}{c|}{ Sum of active temperatures by } \\
& \multicolumn{3}{|c|}{ years, $+5{ }^{\circ} \mathrm{C}$} \\
\cline { 2 - 7 } & 2019 & 2020 & 2021 & 2019 & 2020 & 2021 \\
\hline Rodina (c) & 6.04 & 28.03 & 15.04 & 224 & 232 & 268 \\
\hline $17-2-41$ & 6.04 & 10.04 & 15.04 & 224 & 355 & 268 \\
\hline $17-3-44$ & 6.04 & 1.04 & 15.04 & 224 & 275 & 268 \\
\hline $17-2-35$ & 7.04 & 29.03 & 15.04 & 238 & 244 & 268 \\
\hline $17-2-26$ & 10.04 & 28.03 & 17.04 & 282 & 232 & 289 \\
\hline $17-2-20$ & 6.04 & 10.04 & 22.04 & 224 & 355 & 342 \\
\hline $17-3-12$ & 7.04 & 8.04 & 22.04 & 238 & 334 & 342 \\
\hline $17-2-44$ & 8.04 & 8.04 & 20.04 & 252 & 334 & 317 \\
\hline $17-3-9$ & 8.04 & 2.04 & 22.04 & 252 & 282 & 342 \\
\hline $17-3-34$ & 8.04 & 5.04 & 17.04 & 252 & 309 & 289 \\
\hline $17-3-13$ & 8.04 & 6.04 & 17.04 & 252 & 317 & 289 \\
\hline $17-3-24$ & 8.04 & 13.04 & 20.04 & 252 & 383 & 317 \\
\hline $17-3-41$ & 8.04 & 7.04 & 20.04 & 252 & 326 & 317 \\
\hline $17-3-10$ & 8.04 & 13.04 & 17.04 & 252 & 383 & 289 \\
\hline $17-3-29$ & 10.04 & 7.04 & 16.04 & 282 & 326 & 278 \\
\hline $17-3-30$ & 11.04 & 5.04 & 15.04 & 296 & 309 & 268 \\
\hline $17-3-27$ & 11.04 & 8.04 & 19.04 & 296 & 334 & 302 \\
\hline $17-2-30$ & 12.04 & 2.04 & 18.04 & 309 & 282 & 302 \\
\hline $17-3-19$ & 9.04 & 14.04 & 22.04 & 266 & 393 & 342 \\
\hline $17-3-22$ & 9.04 & 14.04 & 22.04 & 266 & 393 & 342 \\
\hline $17-3-48$ & 11.04 & 14.04 & 17.04 & 296 & 393 & 289 \\
\hline $17-3-16$ & 12.04 & 14.04 & 22.04 & 309 & 393 & 342 \\
\hline & & & & & & \\
\hline
\end{tabular}

According to the start of the growing season, these hybrid forms of walnut were ranked into two groups. The early ones included walnut forms from April 6 to April 7 - 17-2-20, 17-2-35, 17-2-41, 17-3-44, 17-3-12; by the late ones from April 11 to April 12, seedlings were sown - 17-3-48, 17-3-30, 17-3-27, 17-230, 17-3-17.

The phase of blooming of walnut fruit buds in 2020 began from March 28 to April 14, 8 days earlier than 2019, due to the rather warm first and third decades of March, the sum of active temperatures for the growing season ranged from 232 to $393{ }^{\circ} \mathrm{C}$. The difference at the beginning of the growing season between early and late hybrid forms was 16 days. With an early start of the growing season from March 28 to April 2, walnut seedlings were observed - 17-2-35, 17-3-44, 17-3-9, 17-2-26, 17-2-30; the late start of the growing season from March 13-14 is observed in seedlings - 17-3-10, 17-3-19, 17-3-22, 17-3-48, 17-3-16, 17-3-24. Due to the cold and prolonged spring, the growing season of walnut in 2021 began quite late (from March 15-22), the sum of active temperatures for the growing season ranged from 268 to $342{ }^{\circ} \mathrm{C}$. The difference at the beginning of vegetation between early and late hybrid forms was 7 days. The early growing season from March 15-17 is noted in forms - 17-2-41, 17-3-44, 17-2-35, 17-3-34, 17-3-13, 17-3-10, 17-2-26, 17-3-29, 17-3-48, 17-3-30; the late growing season on March 22 was noted in seedlings - 17-3-16, 17-3-19, 17-3-22, 17-3-48. Based on the vegetation analysis carried out during the 3-year period, all remaining hybrid seedlings are 17-2-20, 17-3-12, 17-2-44, 17-3-9, 17-3-34, 17-3-13, 17-3-24, 17-3-41, 
17-3-10, 17-3-29, 17-3-30, 17-3-27, 17-2-30 are attributed to the average period of the beginning of the growing season. It was found that the hybrid forms of walnut with an early start of the growing season - 17-2-41, 17-3-44, 17-2-35, 17-2-26; with a late start of the growing season $\mathrm{k}$ (the most valuable for breeding and production) $-17-3-48,17-3-16$, 17-3-19, 17-3-22.

Spring 2020 was distinguished by the presence of stresses with temperature changes in the second decade of April, in the phase of swelling of fruit buds, there was a sharp decrease in air temperature from $+10.4{ }^{\circ} \mathrm{C}$ to $-2.7{ }^{\circ} \mathrm{C}$, which caused severe freezing of male inflorescences, damage to pistillate flowers and damage to vascular tissues of annual wood (Figure 1).

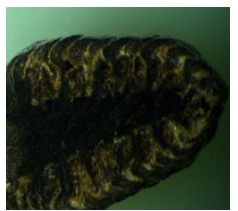

a

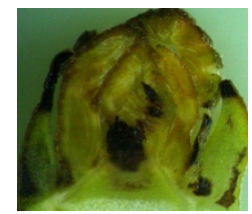

$\mathrm{b}$

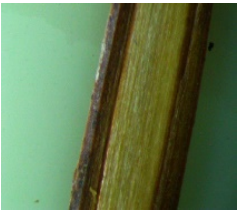

$\mathrm{c}$

Fig. 1. Microphoto of a longitudinal section (magnification $10 \times 10 \times 10$, without dye): a - male bud; $\mathrm{b}$ - female bud of nut; $\mathrm{c}$ - one-year shoot, April 2020, microscope (Micromed MC2 Zoom 2A).

The presence of spring damage to the walnut was noted in each hybrid form according to the generally accepted method. The degree of freezing was determined on a 5-point scale. According to the degree of damage, hybrid forms of walnuts from spring frosts are divided into two groups: moderately resistant to spring return frosts ( 2 points) and weakly resistant to spring return frosts (3 points). Seedlings from the family are classified as medium-resistant (2 points) (Ideal f. p., Ya-Yu-40 f. p., Dachny f. p., Ya-Yu-50 f. p.) - 17-2-20, 17-2-26, 17-2-30, 17-2-35, 17-2-41, 17-2-44, 17-3-12, 17-3-13, 17-3 -16, 17-3-22, 17-3-24, 17-3-27, 17-3-29, 17-3-30, 17-3-34, 17-3-41, 17-3-44, 17-3-48; weak-resistant (3 points) include forms from the family (Ya-B-84 f. p.) - 17-3-9, 17-3-10, 17-3-19. In all studied hybrid forms of walnut, annual wood was damaged to varying degrees, which led to the awakening of dormant buds in some areas of the skeletal branches. The death of male earrings and a decrease in yield were also noted (table 2).

The assessment of the general condition of walnut seedlings after the winter period at the beginning of the growing season in 2021 was also determined according to the generally accepted method on a 5-point scale. The hybrids were ranked into two groups: in good condition (4 points) and weakened condition (3 points). Seedlings from the family (G-3-9, variety Dachny, Ya-Yu-50) - 17-2-26, 17-2-30, 17-2-35, were attributed to the forms in good condition (4 points), 17-3-12, 17-3-48, 17-2-20, 17-2-41, 17-3-16, 17-3-22, 17-3-24, 17-3-27, 17-3-29, 17-3-30, 17-3-34, 17-3-41, 17-3-44; a weakened state (3 points) was noted in hybrids from the family (Ya-Yu-40, Ya-B-84) - 17-2-44, 17-3-9, 17-3-10, 17- 3-13, 17-3-19. Ananalysis of freezing from spring return frosts and an assessment of the general condition at the beginning of the growing season showed that all hybrid forms of Asian walnut are susceptible to damage from low temperatures to varying degrees, most damage was noted in hybrid seedlings from the family (Ya-B-84). This fact is due to the fact that the seedlings obtained from (Ya-B-84) are hybrids of the second generation from the Central Asian variety Bostanlyksky, while other hybrid families have Central Asian forms in the third and fourth generations. Thus, the low adaptability in the conditions of the North Caucasus in the Ya-B-84 seedlings is explained by the significant presence of introduced gene plasma in their origin. 
Table 2. Freezing of vascular-conducting tissues in annual shoots of hybrid forms of walnut spring 2020

\begin{tabular}{|c|c|c|c|c|c|c|}
\hline \multirow{2}{*}{$\begin{array}{l}\text { Variety, } \\
\text { the form }\end{array}$} & \multirow{2}{*}{ Origin } & \multirow{2}{*}{$\begin{array}{c}\begin{array}{c}\text { Freezing } \\
\text { degree, } \\
\text { point }\end{array} \\
\text { April, } \\
2020\end{array}$} & \multicolumn{4}{|c|}{ General condition assessment, score } \\
\hline & & & 2019 & 2020 & 2021 & $\begin{array}{c}\text { average } \\
\text { score }\end{array}$ \\
\hline Rodina (c) & $\begin{array}{c}\text { selection } \\
\text { from local } \\
\text { populations }\end{array}$ & 2.0 & 5.0 & 5.0 & 4.0 & 4.6 \\
\hline $17-2-44$ & $\begin{array}{l}\text { I-Yu-40 } \\
\text { f. p. }\end{array}$ & 2.0 & 5.0 & 5.0 & 3.0 & 4.3 \\
\hline $17-3-34$ & \multirow{3}{*}{$\begin{array}{l}\text { I-Yu-50 } \\
\text { f. p. }\end{array}$} & 2.0 & 5.0 & 5.0 & 4.0 & 4.6 \\
\hline $17-3-41$ & & 2.0 & 5.0 & 5.0 & 4.0 & 4.6 \\
\hline $17-3-44$ & & 2.0 & 5.0 & 5.0 & 4.0 & 4.6 \\
\hline $17-2-20$ & \multirow{5}{*}{$\begin{array}{l}\text { Ideal } \\
\text { f. p. }\end{array}$} & 2.0 & 5.0 & 5.0 & 4.0 & 4.6 \\
\hline $17-2-26$ & & 2.0 & 5.0 & 5.0 & 4.0 & 4.6 \\
\hline $17-2-30$ & & 2.0 & 5.0 & 5.0 & 4.0 & 4.6 \\
\hline $17-2-35$ & & 2.0 & 5.0 & 5.0 & 4.0 & 4.6 \\
\hline $17-2-41$ & & 2.0 & 5.0 & 5.0 & 4.0 & 4.6 \\
\hline $17-3-24$ & \multirow{5}{*}{$\begin{array}{c}\text { Dachny } \\
\text { f. p.. }\end{array}$} & 2.0 & 5.0 & 5.0 & 4.0 & 4.6 \\
\hline $17-3-27$ & & 2.0 & 5.0 & 5.0 & 4.0 & 4.6 \\
\hline $17-3-29$ & & 2.0 & 5.0 & 5.0 & 4.0 & 4.6 \\
\hline $17-3-30$ & & 2.0 & 5.0 & 5.0 & 4.0 & 4.6 \\
\hline $17-3-48$ & & 2.0 & 5.0 & 5.0 & 4.0 & 4.6 \\
\hline $17-3-9$ & \multirow{7}{*}{$\begin{array}{l}\text { I-B-84 } \\
\text { f. p. }\end{array}$} & 3.0 & 5.0 & 5.0 & 3.0 & 4.3 \\
\hline $17-3-10$ & & 3.0 & 5.0 & 5.0 & 3.0 & 4.3 \\
\hline $17-3-12$ & & 2.0 & 5.0 & 5.0 & 4.0 & 4.6 \\
\hline $17-3-13$ & & 2.0 & 5.0 & 5.0 & 3.0 & 4.3 \\
\hline $17-3-16$ & & 2.0 & 5.0 & 5.0 & 4.0 & 4.6 \\
\hline $17-3-19$ & & 3.0 & 5.0 & 5.0 & 3.0 & 4.3 \\
\hline $17-3-22$ & & 2.0 & 5.0 & 5.0 & 4.0 & 4.6 \\
\hline
\end{tabular}

\section{Conclusions}

At the moment, in the breeding of walnuts, it is important to create cold-resistant varieties that are less susceptible to the influence of low temperatures in winter and spring return frosts, which are often found in the North Caucasus. Based on breeding research, according to the longterm data from (2019-2021), hybrid forms of walnut with an early start of the growing season were identified: 17-2-41, 17-3-44, 17-2-35, 17-2-26; and the most valuable for selection and production with a late start of the growing season: 17-3-48, 17-3-16, 17-3-19, 17-3-22. It has also been established that hybrid families of walnuts (Ideal f. p., Ya-Yu-40 f. p., Dachny f. p., Ya-Yu-50 f. p.) are moderately resistant to returnable spring frosts, to these include seedlings - 17-2-20, 17-2-26, 17-2-30, 17-2-35, 17-2-41, 17-2-44, 17-3-13, 17-3- 16, 17-3-22, 17-3-24, 17-3-27, 17-3-29, 17-3-30, 17-3-34, 17-3-41, 17-3-44, 17-3-48. All studied forms are of interest for further breeding study. 


\section{References}

1. A. Khadivi, A. Montazeran, P. Yadegari, Sci. Hortic., 253, 147-153 (2019) https://doi.org/10.1016/i.scienta.2019.04.041

2. C. K. Augspurger, Ecology, 94 (1), $41-50$ (2013) https://doi.org/10.1890/12-0200.1

3. L.V. Artyukhova, Yu.F. Yakuba, I.M. Balapanov, Fruit growing and viticulture of South Russia, 67(1), 55-65 (2019) http://doi.org/10.30679/2219-5335-2021-1-67-55-65

4. Z. Hajinia, S. Sarikhani, K. Vahdati, Genet. Resour. Crop. Evol., 68, 2325-2336 (2021) https://doi.org/10.1007/s10722-021-01131-6

5. S.N. Cosmulescu, M. Bîrsanu Ionescu, C. Netoiu, Not. Sci. Biol.,11(2), 304-308 (2019) https://doi.org/10.15835/nsb11210492

6. V. Slavskiy, S. Horbachenko, IOP Conf. Ser.: Earth Environ. Sci., 595, 012049 (2020) https://doi.org/10.1088/1755-1315/595/1/012049

7. V. Slavskiy, A. Vodolazhskiy, Biganova S. IOP Conf. Ser.: Earth Environ. Sci., 226, 012016 (2019) https://doi.org/10.1088/1755-1315/226/1/012016

8. V.A. Slavsky, M.P. Chernyshov, Forestry engineering journal, 8(1), 72-80 (2018) https://doi.org/10.12737/article_5ab0dfbd226477.15826387

9. S. Paź-Dyderska, A.M. Jagodziński, M.K. Dyderski, Reg Environ Change 21, 18 (2021) https://doi.org/10.1007/s10113-020-01745-z

10. A Hassankhah, K. Vahdati, M. Rahemi, D. Hassani, S. Sarikhani Khorami, Int. J. Hortic. Sci. Technol., 4(2), 259-271 (2017) https://doi.org/10.22059/ijhst.2018.260944.249

11. K.B. Szügyi, G. Bujdosó, V. Hajnal, L. Szalay, Acta Hortic., 1172, 391-394 (2015) https://doi.org/10.17660/ActaHortic.2017.1172.74

12. I. Balapanov, L. Artykhova, E3S Web Conf., 254, 01024 (2021) https://doi.org/10.1051/e3sconf/202125401024

13. A. Ebrahimi, A. Khadivi-Khub, Z. Nosrati, R. Karimi, Sci. Hortic., 193, 195-201 (2015) https://doi.org/10.1016/j.scienta.2015.06.049

14. I. Balapanov, I. Suprun, I. Stepanov, S. Tokmakov, A. Lugovskoy, Sci. Hortic., 253, 322326 (2019) https://doi.org/10.1016/j.scienta.2019.04.014

15. J.D. Tanner, K.Y. Chen, M.M. Jenderek, S.J. Wallner, I.S. Minas, Cryobiology, 101, $87-$ 94 (2021) https://doi.org/10.1016/j.cryobiol.2021.05.003 